\title{
Rusijos „valdžios vertikalè“: 2003-2004 m. rinkimų ciklo peripetijos
}

\begin{abstract}
Straipsnyje nagrinëjama Rusijos vidaus politikos proceso sudedamojo ir išskirtinio elemento, vadinamojo rinkimų ciklo, apimančio 2003 metų Valstybès Dūmos ir 2004 metų prezidento rinkimų laikotarpius, demokratiškumo problema. Pirmiausia pateikiama politinio režimo, kaip esminio veiksnio, darančio itaką rinkimų turiniui, bendroji prieš rinkimus išryškejjusi charakteristika. Ypatingas dėmesys skiriamas Valstybès Dūmos ir prezidento rinkimų kampanijų procedūrų eigos demokratinių reikalavimų pažeidimams bei analizuojama proprezidentinès partijos „Vieningoji Rusija“ išskirtine programine „demokratine““ pozicija dèl vyriausybès formavimo remiantis rinkimų į Dūmą rezultatais. Aptariami rinkimų politiniai rezultatai, kurie dar ketveriems metams legitimizavo Putino vykdomą politinès monocentristinès valdžios stiprinimo ir demokratinių procesų „išaldymo“ kursą, pabrèžiama, kad tai pasiekta pažeidžiant demokratini atstovavimo principą, kadangi rinkimų procedūrų metu nebuvo užtikrintos lygios sąlygos visiems politinių varžybų dalyviams. Taigi pastarieji rinkimai netapo tolesnès demokratijos sklaidos indikatoriumi.
\end{abstract}

\section{Ivadas}

Pokomunistinės Rusijos raida, vykstanti jau daugiau kaip dešimtmetį, ir ją lydintys teoriniai samprotavimai, praktiniai veiksmai, išryškėję tam tikri proceso dėsningumai bei paradoksai yra politikos mokslo dėmesio, pasireiškiančio visomis galimomis formomis, objektas. Bene konceptualiausia problema, kurią sprendžia tyrejjai, yra tiesiogiai susijusi su sąvoka ,demokratijos transformacijos“, suprantama plačiaja prasme. Kitaip sakant, ieškoma tikslesnių atsakymų ǐšiuos principinius klausimus: kodèl nepriklausomoje Rusijoje vykstant demokratizacijos procesui nebuvo pasiekta pastebimų rezultatų, kodèl sukurtai politinei valdžios sistemai būdingesni tarpinio politinio režimo požymiai, kas lemia, kad pernelyg letai igyvendinami politinio demokratinio gyvenimo principai, kiek ịvairiose valstybès ir visuomenès gyvenimo srityse demokratijos laimëjimai-ivvkę pokyčiai - yra gilūs ir negrižtami, pagaliau - ar galime artimiausioje ateityje tikètis sèkmingos demokratijos jëgų konsolidacijos? Tačiau nuo 2000 metų prasidëję Rusijos vidi-

"Dr. Virgilijus Pugačiauskas - Lietuvos karo akademijos Politikos mokslų katedros docentas. Adresas: Šilo g. 5 A, 10322 Vilnius, tel. 8-5 2103569, el. paštas v.pugaciauskas@lka.lt 
nès politinès raidos kai kurie ryškūs pokyčiai suteikè progą gerokai suabejoti ne tik konsolidacijos perspektyva, bet ir demokratinių procesų tęstinumo galimybe ${ }^{1}$.

Kaip žinoma, Rusijoje demokratizacija didžiausių laimėjimų pasiekè rinkimų srityje, tiksliau sakant, jie vyksta daugiau ar mažiau remiantis demokratinėmis rinkimų procedūromis, legitimizuojančiomis naujai išrinktą valdžią. Beje, šis principas igyvendintas pirmą kartą valstybės istorijoje. Rinkimų sistemos funkcionavimas remiasi demokratinių rinkimų teisine baze, taip pat lyg ir atitinka bent jau formalius procedūrinius kriterijus (tiesioginiai, visuotini, lygūs, slapti, konkurenciniai, periodiški). Tai liudija, kad gerbiamos demokratijos taisyklès ir demonstruojamos politinio režimo demokratinès nuostatos - vyriausybė gauna demokratinę legitimaciją, o politinis elitas nekvestionuoja rinkimų rezultatų. Tai vienintelis rimtesnis kriterijus, leidžiantis Rusiją priskirti šiuolaikinių „elektorinès demokratijos“ (ryškiausias ir bendriausias, politinį režimą apibūdinantis požymis) valstybių grupei.

Tačiau tokia charakteristika, be gausių išimčių, įmanoma tik dẻl paviršutiniško ir dažniausiai formalaus požiūrio, kadangi po kiekvienų iki tol (nuo 1993 m.) vykusių rinkimų nepriklausomi, kaip antai Europos saugumo ir bendradarbiavimo (ESBO) organizacijos, stebetojai konstatuodavo ịvairių pažeidimų, tačiau jie nepasiekdavo kritinès ribos, kad būtų îvertinti kaip akivaizdūs demokratijos pažeidimai.

Pagrindinis straipsnio tikslas - nustatyti, kaip vienas iš svarbiausių Rusijos vidinio politinio proceso reiškinių - 2003-2004 metų rinkimų ciklas - atitinka demokratiniu rinkimų standartus. Pirmiausia pateikiama iki rinkimų vyravusio politinio režimo, kaip esminio veiksnio, darančio įtaką rinkimų turiniui, bendroji charakteristika, tačiau ypatingas dėmesys skiriamas pažeidimams, bandoma nustatyti, kiek Valstybės Dūmos ir prezidento rinkimų kampanijų procedūriné eiga neatitinka demokratijos reikalavimų, siekiant pateikti išvadas apie rinkimų rezultatų itaką politinio režimo stiprëjimo tendencijai ateityje.

\section{Politinès sistemos funkcionavimas: monocentristinès valdžios stiprèjimo pliusai ir minusai}

Rinkimų reikšmė politinių režimų raidai yra labiau nei akivaizdi, jų svarba tampa reikšminga trečiosios demokratijos bangos tarpiniams politiniams režimams. Rusijos rinkimų praktikos analizė taip pat gerokai palengvina paieškas siekiant suprasti ir apibūdinti transformacijos procesus, turint omenyje, kad rinkimai sudaro praktiškai nenutrūkstamą ciklą, i kurị įsiterpia šiek tiek daugiau kaip tris mėnesius trunkantis periodas tarp rinkimų. Kita vertus, rinkimai yra vertintini kaip viena iš esmingiausių Rusijos demokratizacijos prielaidų.

\footnotetext{
${ }^{1}$ Russia After the Soviet Union, London: Longman, 1999; Sakwa R., Russian politics and society, 3nd edition, London: Routledge, 2002; Brown A., „Russia and democratization“, Problems of PostCommunism, 1999, Vol. 46, No. 5; Russia's Unfinished revolution: Political Change from Gorbachev to Putin, Ithaca, NY: Cornell University Press, 2001; Гельман В., „Transition“ по-русски: концепции переходного периода и политическая трансформация в России (1989-1996), Общественные науки и современность, 1997, №. 4; McFaul M., Petrov N., Ryabov A., Between dictatorship and democracy Russian post-Communist Political Reform, Carnegie Endowment for international Peace, 2004; Colton T. J., McFaul M., „Russian Democracy Under Putin“, Problems of Post-Communism, July-August 2003, Vol. 50, No. 4.
} 
Prieš pradedant tiesiogiai aiškintis beveik pusès metų trukmės rinkimų ciklo problemas, pirmiausia dera apžvelgti periodą iki rinkimų, tiksliau sakant, politinès sistemos funkcionavimo ypatybes ir esminius pokyčius prezidento Vladimiro Putino valdymo laikotarpiu. Ryškiausias pokytis politinio vaidmens srityje įvyko, kai pirmosios Putino kadencijos pabaigoje susiformavo dauguma monocentristinès valdžios bruožų - prezidentas tapo vieninteliu ir realiu valdžios galios centru, nustatančiu politinio proceso judejimo strategines kryptis ir diena iš dienos vis tvirčiau kontroliuojančiu politinio režimo veikimo kanalus ir jo pagrindinius žaidejus. Pasiektas bendras rezultatas, Rusijos nepriklausomu analitikų apibūdinamas žodžiu „stabilumas“, vienokiu ar kitokiu lygiu apima visas valstybės gyvenimo sritis. Dar daugiau - tie rezultatai tapo tokie akivaizdūs, radikalūs ir nekvestionuojami, kad imta plačiai diskutuoti, kaip jie smarkiai pakeité politinio režimo bruožus ${ }^{2}$.

Pirmaisiais kadencijos metais iš esmès Putinąs sprendè vienintelę konceptualią politinę problemą - visais įmanomais būdais stengèsi neutralizuoti grèsmes, kylančias valstybės dezintegracijai, kurias gavo kaip tiesioginis Boriso Jelcino politinio palikimo paveldètojas. Pirmuosius veiksmus po rinkimų prezidentas sukoncentravo ị centrinès valdžios stiprinimo procedūras, pradėjo nuo ją labiausiai silpninančiu grandžių: èmè siaurinti regioninio elito plačias autonomines teises ir mažinti oligarchų įtaką Kremliaus priimamiems politiniams sprendimams.

Pirmajai problemai sèkmingai spręsti pakako dviejų radikalių administracinių sprendimų. Pirma, buvo įsteigtos septynios apygardos, kurioms vadovavo prezidento skirti ịgaliotiniai, turintys plačias ir ne itin aiškiai apibrëžtas funkcijas, siekiant užtikrinti centrinių ir regioninių valdžios institucijų veiksmų koordinavimą, kas savaime gerokai sumenkino regioninio elito plačios politinès autonomijos laipsnị. Antra, buvo atlikta Federacinès Tarybos reorganizacija - atimta iš gubernatorių ir regioninių ịstatymų leidybos institucijų vadovų teisè būti jos nariais, o tai reiškẻ neliečiamybès statuso praradimą ir politinès veikimo laisvès susiaurinimą valstybiniu lygmeniu ${ }^{3}$. Tiesa, čia dar vertètų prisiminti, kad prezidentui pavyko santykiuose su Valstybės Dūma išvengti ne tik beveik tradicija tapusios konfrontacijos, bet ir sukoncentruoti bei grịsti politinị bendravimą su skirtingų partijų deputatais ne ideologinio, bet išimtinai pragmatinio dialogo principais, o tai savo ruožtu gerokai sumažino opozicinę priešpriešą ir Dūmos ịtakąa .

\footnotetext{
${ }^{2}$ Шевцова Л., „Президент Путин оформляет собственный политический режим: что из этого следует“", http://www.carnegie.ru/ru/print/69486-print.htm, 200501 23; Зудин А. Ю., „Режим В. Путина: контуры новой политической системы“, Общественные науки и современность, 2003, №. 2, с. 67; Putinas užsitikrino šalies piliečiu solidų (nenukrintantị žemiau kaip 50 proc.), stabilų (10 proc. paklaida) ir, kas ịdomiausia, beveik nepriklausantị nuo esamos konjunktūros palaikymą. „B. Путин: рейтинг неизменен - имидж меняется“", http://www.bd.fom.ru/report/cat/president2/putin/ rating_Putin/d023924, 200411 12; „Рейтинг Путина обвалится через год?“, http://www.cipkr.ru/ publication/p010604.html, 20040910.

${ }^{3}$ Rogoża J., Wiśniewska I., A summary of the politico-economic changes taking place during Vladimir Putin's first term of office, Prace OSW (Centre For Earter Studies), Warszawa, 2003, No. 11, p. 17 18, 55-56; Петров Н., „Puzzle федеральной реформы: 4 года спустя“, http://www.carnegie.ru/ru/print/ 69803-print.htm arba http://www.themoscowtimes.com/stories/2004/02/17/006.hml, 20040510.

${ }^{4}$ Bielinis L., „Kremliaus sprendimus diktuoja šalies politinè inercija“, Tarptautinè politika: komentarai ir interpretacijos, Vilnius: Eugrimas, 2002, p. 181.
} 
Antrają problemą Putinas taip pat sprende rezultatyviai: panaudojus ekonominès ir teisinès prievartos metodus, labiausiai politikuojantys oligarchai prarado galimybę daryti tiesioginę įtaką Kremliuje priimamiems politiniams sprendimams, jų galia buvo galutinai neutralizuota. Tokiu būdu prezidentas vienašališkai nustatẻ naujus Kremliaus ir oligarchų bendravimo principus, tokius kaip politinè subordinacija ir lojalumas, neleisdamas viešai oligarchams politikuoti ${ }^{5}$. Žinoma, jų laikytis tapo privalu ir kitiems šio išskirtinio klubo nariams. Belieka dar pridurti, kad lygiagrečiai Kremliaus pozicijų stiprinimo procesą lydejjo lẻtas ekonomikos kilimas, nulemtas ne tiek konkrečios ir sèkmingos valdžios ekonominès politikos, kiek nuolat palankios tarptautinès konjunktūros, išlaikančios aukštą ir stabilų pasaulinių strateginiųžaliavų kainų lygị.

Taigi Rusijos vidinès raidos stabilizacija laikytina didžiausiu pirmosios kadencijos laimèjimu, pasiektu sutelkus realius valdžios svertus vienose rankose ir tuo pat metu letais ir atsargiais veiksmais taisant padètį tose anarchijos stadijoje esančiose pagrindinèse valstybès gyvenimo srityse, be kurių negalima toliau judèti - veikti siekiant normalios būsenos. Iš tiesų stiprejjančiụ Kremliaus galių fone valdžios antikriziniuose veiksmuose galima ižvelgti ir tam tikrus sumanymus valdymo sistemai moderninti ir konkrečius mėginimus juos pritaikyti praktiškai, pavyzdžiui: partiju įstatymo prièmimas, teismų ir prokuratūros, mokesčių sistemos, žemès ir karinių pajègų reformos. Tiesą pasakius, daugelis šių projektų dèl gausybès tiek objektyvių, tiek subjektyvių veiksnių netapo politinių ir socialinių, o ypač ūkinių ir struktūrinių permainų katalizatoriais ir sugebėjo pasiekti dažniausiai tik vidutinị ar minimalu praktinio igyvendinimo lygmeni, taigi ir galutinis rezultatas taip pat buvo menkas ${ }^{6}$. Visapusiškai vertinant situaciją svarbu pridurti ir tai, kad vadinamieji modernizaciniai valdžios sprendimai tarp kitų antikrizinių veiksmų akivaizdžiai modifikavosi. Iš esmès jais pirmiausia buvo siekiama ne pagerinti situaciją, bet ją normalizuoti.

Kita vertus, Kremliaus antikriziniai veiksmai, tape vieninteliu prioritetiniu tikslu (nes tai buvo ne kas kita, o valstybės išlikimo problema), galima sakyti, palengva , „išaldë“ bendrą ganètinai chaotiškai vykusį demokratejjimo procesą, netgi daugiau - èmé palaipsniui ryškèti demokratijos pozicijų siaurinimo tendencija. Tiksliau sakant, valdžios energingi veiksmai, nukreipti valstybės stabilumui užtikrinti, slopino žodžio ir spaudos laisvę, kai buvo uždaryti (arba apribota jų veikla) opoziciniai spaudos ir televizijos kanalai (kai kurie jų dèl to, kad priklausé oligarchams, patekusiems i Kremliaus nemalonę) $)^{7}$. Kita vertus, Putinas savo kadrų politika, paskirdamas i atsakingiausius civilinès valdžios postus karinių struktūrų ir specialiụjų tarnybų pareigūnus (kas ketvirtas - politinio elito atstovas), gerokai padidino specialiujų tarnybų tiesioginị vaidmenị valstybės valdyme, kas, savaime suprantama, prieštarauja demokratinès tvarkos logikai ${ }^{8}$.

\footnotetext{
${ }^{5}$ Фортескью С., „Правит ли Россией олигархия?““, Полис, 2002, №. 5, с. 64-73.

${ }^{6}$ Plačiau žr.: Shevcova L., Putin's Russia, Washington: Carnegie endowment for international peace, 2003, p. 104-133, 187-196; Laurinavičius Č., „О военной реформе в России”, Lietuvos Rytu kaimynai: Politika ir saugumas. Tarptautinès mokslinès konferencijos medžiaga, Nr. 7, Vilnius: Leidybos centras prie KAM, 2002, p. 25-28.

${ }^{7}$ Politologai, lygindami politinę konjunktūrą prieš 1999 m. ir 2003 m. rinkimus, Putino igyvendintas „reformas“ ivardijo kaip antidemokratinius pertvarkymus, sukūrusius daugybę kliūčiu politiniams oponentams būsimuose rinkimuose. McFaul M., Petrov N., "What the Elections Tell Us", Journal of Democracy, July 2004, Vol. 15, No. 3.

${ }^{8}$ Крышмановская О., „Режим Путина: либеральная милитократия“, Pro et Contra, Т. 7, 2002, №. 4.
} 
Galima teigti, kad nuo šio momento prezidento galių stiprinimo tendencija evoliucionavo nuo vienkartinių veiksmų politikos iki prioritetinès politinès programos. Taip jai buvo suteiktas oficialios politikos statusas ir tuo pat metu stabdoma visuomeninių demokratinių institucijų raida. Šios politikos fone pamažu ryškẻja ir naujas valdžios požiūris į tolesnę demokratijos plètrą - problemų sprendimas atidedamas tolesnei ateičiai, motyvuojant Rusijos specifiškumu, trukdančiu jai būti imliai priimti vakarietiško demokratinio gyvenimo patirtị.

Tiesa, gerokai sustiprintos prezidento galios ir stabilizuota politinè bei socialinè aplinka pirmosios kadencijos pabaigoje suteikè Putinui ir alternatyvių galimybių, pavyzdžiui, ị politinę dienotvarkę buvo įtraukti ir imti spręsti kokybiškai nauji valstybès demokratinès transfomacijos uždaviniai. Žinoma, praktiškai tai galèjo būti pradèta igyvendinti tik po rinkimų ciklo - parlamento ir prezidento rinkimų.

\section{Valstybès Dūmos rinkimai: demokratiškumo paieškos}

Pirmosios Putino kadencijos pabaigoje svarbiausiu politiniu įvykiu neabejotinai tapo rinkimai į Valstybès Dūmą, nepaisant akivaizdžiai suvaržytų šios institucijos galimybių konstruoti politinius procesus. Tačiau būtent šioje valdžios institucijoje igyvendinamas, nors ir minimaliu lygiu, politinis pliuralizmas. Ypač svarbu yra ir tai, kad Dūma sudaroma remiantis laisvų rinkimų principu ịvairių konkuruojančių politinių pakraipų partijų varžytuvėse.

Prieš rinkimus politinè situacija šalyje, palyginti su ankstesniais 1999 metų rinkimais, gerokai pasikeitè ir priklausè, kaip jau minèta, nuo naujų anksčiau išvardytų veiksnių. Šiuo atveju, pasak politologo Andrejaus Riabovo, būtent prezidentas, jo administracija arba tiesiog Kremlius tapo pagrindiniu rinkimų žaidejju, lemiančiu rinkimų dienotvarkę ir prieš rinkimus vykstančios kovos kryptį, o partijos ir vadinamieji rinkimų susivienijimai tik prisitaikè prie rinkimų situacijos ${ }^{9}$. Be to, reikia pabrèžti, kad dar prieš rinkimus pirmą kartą Kremliaus galia pasiekė aukščiausią lygi, o tai savo ruožtu reiškè, jog jị remiančios politinès jègos gali tikètis svaresnès nei anksčiau visokeriopos paramos.

Kremlius siekè ne tik įtvirtinti pasiektus laimëjimus Dūmoje, bet ir užsitikrinti kuo palankesnịjį remiančių Dūmos deputatų mandatų skaičių. Tikslui pasiekti buvo naudojamas tradicinis būdas - „valdžios partija“"10. Konkretūs veiksmai šia linkme prasidejjo 2001 metais, kai buvo sujungtos dvi politinès jègos - „Tèvyne““ ir „Vienybë“, kurios tapo viena visuomenine organizacija, o vèliau partija. Palyginti su ankstesniais rinkimais, abiejų politinių žaidejų prieš rinkimus buvusios pozicijos gerokai transformavosi prezidento naudai - stipraus pirmojo politiko atvirai reiškiama parama šikart partijai suteikẻ daugiau politinių dividendų, o ne atvirkščiai. Pastaroji aplinkybè ir partijos vadovybès aktyvūs bei reguliarūs veiksmai sparčiai didinant partijos narių ir šalininkų gretas ir, kas svarbiausia, tiesioginė galimybė naudotis

\footnotetext{
${ }_{9}^{9}$ Пресс-брифинг: „Расстановка сил перед выборами: оценки и прогнозы“, http://www.carnegie.ru/ru/ print/69303-print.htm, 20040511.

${ }^{10}$ Carotbers T., „Democracy: no party for parties“, Rough crossing democracy in Russia, Moscow: Neostrom Publisters, 2004, p. 75-76.
} 
neišsenkančiais valdžios administraciniais ištekliais (rus. ,административный pecypc") sudare itin palankias sąlygas partijai sėkmingai kaupti potencialias jëgas ir siekti rinkejų palankumo ${ }^{11}$.

Tiesa, reikia turèti omenyje dar vieną palankių aplinkybių, susijusių su administracinių išteklių panaudojimu, ypač regionuose, aspektą. Visų lygių valdžios biurokratijai buvo lengva apsispręsti, kadangi iš anksto tapo aiškūs rinkimų, ypač prezidento, favoritai, todèl beliko tik priderinti savo veiksmus prie išryškẻjusios politinės konjunktūros ir paremti proprezidentinę politinę jègą.

Taigi 2003 m. gruodžio $7 \mathrm{~d}$. vykę rinkimai iš esmès sprendè vieną vienintelę politinę intrigą - kiek deputatų mandatų atiteks valdžios partijai „Vieningoji Rusija“. Skirtingų visuomenès nuomonès tyrimo centrų ankstyvosios, prieš rinkimus atliktos, apklausos taip pat liudijo, kad „valdžios partija“ neturètų susidurti su didesnèmis kliūtimis, kadangi atsirado naujų palankių momentų. Pagrindinés nusilpusios politinès jègos, kaip antai Komunistų partija, nesugebẻjo pagausinti savo šalininkų gretų ir gerokai atsiliko, o abiejų dešiniųjų partijų galimybès netgi peržengti numatytą procentinį barjerą išliko abejotinos dèl nesugebejjimo suderinti bendrų veiksmų ${ }^{12}$. Šių veiksnių konjunktūros sukurtoje erdvejje būtų tikslinga aiškintis tolesnius svarbesnius rinkimų aspektus, kai į konkurencinę kovą įsitraukẻ 23 politinės partijos ir visuomeniniai judèjimai, dalyvaujantys savarankiškai ar susijungę į rinkimų susivienijimus $^{13}$.

Remiantis sociologinių apklausų duomenimis, realiai igyti didesnị pranašumą ir peržengti 5 proc. ribą galëjo tikètis tik 5 dalyviai. Silpniausias pozicijas demonstravo „Jabloko“ ir Dešiniujų jègų sajunga, dèl partijų lyderių asmeninių ambicijų nesugebejjusios susitarti dẻl bendrų agitacinių veiksmų. Tokia tendencija nusistovejo, nepaisant nedidelių svyravimų, iki pat rinkimų agitacinès kampanijos pradžios ir rinkimų dienos, išskyrus tą momentą, kai prieš pat rinkimus smarkiai išaugo „Rodina" reitingai ${ }^{14}$.

\footnotetext{
${ }^{11}$ Partijos statistiniai $2002 \mathrm{~m}$. kovo mėnesio rodikliai: apie 400 tūkst. narių, tarp jų 154 Valstybès Dūmos deputatai, 41 Federacinès Tarybos narys, 6 gubernatoriai partijos taryboje, filialai veikè visuose 89 Federacijos subjektuose, iš viso apie 2400 vietinių skyrių. Верин В., „Единая Россия“ обещает успех“, Парламенская газета, 200304 01, №. 59 (1188); Мнение экспертов, „Развитие партии „Единая Россия“" и состояние партийно-политической системы““, http://niiss.ru/edro.shtml, 200403 05; „Программа „Выборы-2003“, „Съезд партии „Единая Россия“, http://svoboda.org/programs/el/2003/ el.040303.asp, 20040323.

${ }^{12}$ ROMIR, VCIOM - A, „Visuomeninès nuomonès fondas“, liepos-rugpjūčio mèn. visuomenès apklausų duomenys: „Vieningoji Rusija“ - 21-23 proc., RFKP - 17-19 proc., Liberalų demokratų partija - 6-7 proc., „Jabloko“ - 4-5 proc., Dešiniuju jęgų sajunga - 3,5-4,5 proc. Партийные электораты: динамика и перспективы. Аналитический бюллетень, Август 2003, http://www.carnegie.ru/ ru/print/67956-print.htm, 20040412.

${ }^{13}$ „Политические партии в начале предвыборной кампании в Государственную Думу РФ“, http://www.indem.ru/IDD2000/anal/Rim2583.html., 20041111.

${ }^{14}$ Пресс-выпуск \#20: рейтинги партий и политиков, http:// www.levada.ru/press/2003111701.html, 200405 23; Рейтинги партий, http://www.bd.fom./report/cat/policy/party_rating/stat_rating/party_rating_2003/d034401, 20040524.
} 
Kita vertus, reikia prisiminti vieną įdomų momentą, kad, nepaisant žemo partijų ir pačios Dūmos reitingo (eiliniai piliečiai, atsakydami ị klausimą, kokius šalyje vykstančius rinkimus laikytų svarbiausiais, eilès tvarka nurodydavo prezidento, savivaldos, gubernatoriu ir (tik ketvirtoje vietoje!) Dūmos rinkimus, kuriuos beveik prilygino regioniniams ịstatymų leidžiamųjų institucijų rinkimams), prognozės liudijo apie ne mažesni kaip 50 proc. rinkèjų aktyvumą ${ }^{15}$. Tokią disharmoniją įtikinamiausiai galima būtų mėginti aiškinti pernelyg didele priverstinio dalyvavimo tradicijos, atejusios iš netolimos praeities, itaka dabartiniam rinkejjui.

Aptariant rinkimų agitacijos periodo ypatumus derètų atkreipti dèmesị i dar vieną, tyrëjų gerokai primirštą, rinkimų proceso produktą - partijų rinkimų programas, nepaisant akivaizdžios tiesos - Rusijos sąlygomis jas galima vertinti kaip teorinès politinès minties virtualią pasireiškimo formą. Kitaip sakant, tai toks visiškai formalizuotas rusiškosios rinkimų demokratijos atributas vien dèl to, kad praktiškai jų igyvendinti neįmanoma, jeigu jos nesutampa su Kremliaus politine linija. Tačiau šiuo atveju daugiausia mus domintų „,valdžios partija“, kaip potencialiai vienintelè jèga, disponuojanti tam tikra atvira politinès minties igyvendinimo galimybe. Kita vertus, partijos rinkimų programoje ir jos vadovų oficialiose kalbose pastebime naujų siūlymų, susijusių su šalies demokratizacijos proceso stiprinimu.

Iš tikrujjų rinkimų favoritès rinkimų programoje pagrindinis prioritetas - socialiniai ir ekonominiai veiksmai, kurie turètų užtikrinti piliečių gerovès kilimą, tačiau surandame keletą itin konkrečių teiginių, tiesiogiai susijusių su demokratinių procesų gilinimo ir plètros problematika. Si politinè jèga, prisistatanti kaip centristinès orientacijos profesionalų ir pragmatikų partija, pirmiausia atsargiai (,jeigu remiantis parlamentiniais rezultatais bus suformuota vyriausybé"), tačiau pakankamai aiškiai kelia sau tikslą tapti partija, pasirengusia paskelbti „,savo vyriausybės sudètį, nes tik tokia partija gali pretenduoti į valdžią šalyje. Ir mes tam pasiruošę!“. O kad valdžios valdymo optimizavimo problema būtų sẻkmingai išspręsta, ji siūlè panaudoti šešis būdus, iš kurių vienas siejamas su būtinybe sustiprinti partijos įtaką vykdomajai valdžiai, taip pat kalbėjo apie vyriausybès atsakingumą Valstybès Dūmai1 ${ }^{16}$. Kad tokia nuostata neatsitiktinis vertybinis partijos politinis ideologinis orientyras, $\mathrm{o}$ vienas iš efektyvių būdų stiprinti politinio režimo demokratinius procesus, rodo ir ankstesni oficialūs partijos dokumentai ${ }^{17}$.

Kita vertus, programoje rinkejjui kalbama ir apie kitokių demokratinių sprendimų būtinybę (laisva spauda, savivaldos stiprinimas, valdžios atsakingumas), tačiau tai suformuluota itin atsargiai, pavyzdžiui, jei desstoma apie spaudos gynimą nuo

\footnotetext{
${ }_{15}^{15}$ „Опрос населения 200307 03. Отношение к выборам“, www.bd.fom.ru/report/cat/policy/party_rating/ election_2003/attitude to election_/d032608, 20040306.

${ }^{16}$ Предвыборная программа Политической партии “Единая Россия" http://www.edinros.ru/section.html?rid=2092, 20040509.

${ }^{17}$ Pirmą kartą partijos pozicija tiksliausiai ir plačiausiai buvo suformuluota $2002 \mathrm{~m}$. kovo ménesi lyderio Boriso Gryzlovo pranešime, kuriame konstatuojama, kad susiklosčiusi situacija yra problemiškiausias 10 dešimtmečio palikimas ir viena iš kliūčių, trukdančių šaliai politiškai vystytis, kurti „tikrają demokratiją“ ir „visavertę pilietinę visuomenę“. Netgi nurodomas palankus metas problemai spręsti Valstybès Dūmos rinkimai. Tačiau tuo pat metu vèlgi būtinai pabréžiama, kad Konstitucija nenumato tokios galimybès, o Konstitucijos pakeitimai - „ateities klausimas“. Доклад Б. Грызлова на II съезде партии “Единая Россия", http://www.vvp.ru/docs/parties/er/63.html, 20040510.
} 
komercinių struktūrų ir valdžios įtakos, būtinai kalbama apie „socialiai atsakingą spaudą “18. Apibendrinant galima pasakyti, kad partija, apibrezžusi savo prioritetini veiklos uždavini - šalies ekonomikos ir piliečių gerovès kèlimą, jị susieja su politinio režimo atskirų sričių, sakyčiau, labiausiai nutolusių nuo demokratinių standartų, tolesnio palaipsnio demokratizavimo procedūromis.

Taigi partijos pozicija - tęsti transformacijos procesą plètojant demokratiją nebuvo atsitiktinè ir, galima drąsiai sakyti, užèmé konkrečią vietą principinių demokratinių nuostatų sąraše, nepaisant formuluočių dviprasmiškumo, garantuojančio politinio manevro laisvę. Kita vertus, tokia solidi nuostata, nors ir ne pati svarbiausia, vargu ar galejo būti ịtraukta ị programą be išankstinių konsultacijų arba bent tylaus pirmojo šalies politiko pritarimo. Kartu tokia pozicija perša mintį apie Kremliaus ir „Vieningosios Rusijos“, oficialiai pasiskelbusios „Prezidento atrama“, išimtinę patronato santykių dimensiją, užkertančią kelią šiai politinei jëgai igyvendinti savarankiškas iniciatyvas. Tai sumažina netgi „,valdžios partijos“ galimybes sẻkmingai atlikti tarpininko tarp visuomenès ir politinių institucijų vaidmenį. Palyginti su dešiniųjų partijų Dešiniujjų jègų sajungos ir ypač „Jabloko“ rinkimų programomis, deklaruojančiomis prioritetinị demokratinio Rusijos pasirinkimo kelią, „valdžios partijos“ siūlymai yra ne tokie konkretūs ir radikalūs, siūlomi veiksmai gerokai mažesnès apimties, tačiau pozicijos kai kuriais klausimais praktiškai sutampa, pavyzdžiui, didinant parlamento žemesniujų rūmų ittaką (suteikiant kontrolès funkciją) vykdomajai valdžiai-vyriausybei ${ }^{19}$.

Rinkimai, netgi aktyviausiu agitacijos periodu, vyko monotoniškai ir be didesnès konkurencinès įtampos, išskyrus vieninteli išskirtinị atvejį - „Vieningosios Rusijos" radikalų atsisakymą dalyvauti teledebatuose su pagrindiniais politiniais oponentais. Ši pozicija grindžiama formaliu aiškinimu, kad svarbiausi klausimai dèl partijos ideologijos ir pozicijos žinomi, jie išdèstyti programoje ir aptarti suvažiavimuose, be to, itin aktyvus yra partiečių darbas regioniniu lygmeniu. Žinoma, kad tokią rinkimų strategiją lèmè kiti motyvai, nes eiliniai rinkejjai programų nebeskaito, o partijos suvažiavimai nėra transliuojami per visuomenès informavimo priemones.

Tiesa, kalbant apie tokios strategijos pagrịstumą, reikia pabrèžti, kad ji iš tikrujų pasiteisino, nes partija daugiau gavo naudos negu patyrè nuostolių dèl politinių konkurentų ir spaudos priemonių kritikos. Pirmiausia ji, kaip „valdžios partija“, t.y. lyg ir atsakinga už dabartinės valdžios vykdomą politiką, išvengè kitų partijų, ypač Komunistų partijos ir „Jabloko“, gabių oratorių nepalankių klausimų („Jukos“ byla, socialinè hiperdiferenciacija, žemas valstybès tarptautinis statusas) tiesioginiame eteryje, o neišnaudotą laiką - beje, tai pažymi dauguma rinkimų ekspertų - partija su kaupu kompensavo gausiais partijos lyderiu pasirodymais pagrindiniuose valstybei pavaldžiuose televizijų kanaluose (keturis kartus dažniau nei kiti kandidatai, partijos ir rinkimų susivienijimai kartu) ${ }^{20}$.

18 Žr.: 17 nuoroda.

19 „Демократический манифест“, “Основы государственной политики на 2003-2005 г.” http://www.yabloko.ru/Elections/2003/Program_2003/index.html, 200404 10; „Обращение СПС к российским избирателям“ 8 августа 2003 г. http://www.duma.sps.ru/?id=51132, 20040325.

${ }^{20}$ Бадовский Д., „Комментарий в связи с отказом „Единой России“ от участия в теледебатах“, www.carnegie.ru/ru/print/68544-print.htm, 200404 02; Михайлова О., „Старт дан...“, www.indem.ru/idd2000/ index.htm, 20040405. 
Aiškindamiesi tolesnius procedūrinius eigos aspektus susiduriame su administracinių išteklių panaudojimo mastais, sukẻlusiais itin didelių abejonių dèl rinkimų proceso demokratiškumo. Administraciniai ištekliai, kaip vienas ryškiausių rusiškosios rinkimų sistemos bruožų, yra skirstomi ị tris dalis, kurias trumpai būtų galima apibūdinti taip: pirmoji-informacinè, pasireiškianti informacijos monopolija (televizijos kanalai), antroji - pareigybinè: tai dvigubų pareigų suderinimas - partijos vadovo ar aktyvaus šalininko ir valstybės centrinès ar regioninès valdžios institucijos pareigūno, jų vieši pareiškimai dèl tam tikros politinès jëgos rèmimo, trečioji - „priverstine““ - tai rinkejų valios tiesioginis veikimas administracinèmis poveikio priemonèmis bei rinkimu rezultatų klastojimas. Iki tol toks neteisètas agitacijos metodas, skirtas rinkëjams mobilizuoti, labiausiai buvo pastebimas per prezidentines kampanijas, klasikinis pavyzdys - Boriso Jelcino antroji rinkimų kampanija. Beje, jos metu administraciniai ištekliai, nukreipti prieš konkurentus, labiausiai reiškèsi finansiniais ir informaciniais ištekliais ${ }^{21}$.

Šios tendencijos keliamus pavojus agitacinio rinkimų proceso metu, matyt, pirmiausia viešai konstatavo savo pirminėse ataskaitose ESBO stebėtojai, tačiau bene tiksliausiai ir iškalbingiausiai apie tokio reiškinio išplitimą ir daromą poveikị rinkejjams ir rinkimu galutiniams rezultatams byloja , administracinių išteklių“ stebèsenos (monitoringo), atliktos kompetentingos tarptautinės bendrovés „Transparency International“ Rusijos filialo, pastebejimai. Štai stebèsenos metu „Vieningoji Rusija“ buvo paminèta pagrindiniuose informaciniuose šaltiniuose (spaudoje, televizijoje, internete) praktiškai tiek pat kartų kiek visos partijos kartu. Belieka aiškumo dèlei pridurti, kad administracinių išteklių naudingumo koeficientas galejo siekti ne mažiau kaip pusantro karto.

Žinoma, visų pirma partija panaudojo administracinius išteklius (162 kartus) savireklamos tikslams, tačiau nemaža dozè (42 kartai) teko didžiausio konkurento RKP atvirai kritikai ${ }^{22}$. Kita vertus, Strateginių tyrimo centro vadovas politologas Andrejus Piontkovskis, palyginęs favoritès pradines starto pozicijas ir galutinius laimejjimus, konstatavo, kad kaip tik televizija ir tapo svarbiausiu instrumentu, užtikrinusiu visišką pergalę pagrindinei Kremliaus partijai ${ }^{23}$.

Žinoma, su tokiais svariais argumentais negalima nesutikti, tačiau partijos lyderiai savo lakoniškuose vertinimuose (kad laimejo dèl atliktų darbų) apie ši reiškinį neužsimena, tarsi jo visiškai nebūtų buvę. Kiek atviresnis ir diplomatiškesnis buvo partijos rinkimų štabo vadovas Jurijus Volkovas, kuris teigè, kad išnaudoti ne administraciniai, bet „didžiuliai žmogiškieji ištekliai“24 . ESBO stebètojai preliminarioje ataskaitoje, išplatintoje kitą dieną po rinkimų, konstatavo, kad buvo panaudo-

${ }^{21}$ Gelman V., „The Iceberg of Russian Political Finance“, Contemporary Russian Politics, Oxford:University press, 2001, p. 182, 191-192; Воронцова А., Звоновский Б., „Административный ресурс как феномен российского избирательного процесса“, Полис, 2003, №. 6, с. 114-124; Михайлова О., „Предвыборная кампания - 2003: итоги и выводы“, http://www.indem.ru/IDD2000/anal/ MOV31215.htm, 20040610.

22 „От мифов к фактам: использование административного ресурса в избирательной кампании в цифрах“, www.transparency.org.ru/doc/pr231203_rus_01101_2.doc; „Второй промежуточный отчёт мисии ОБСЕ“, http://www.urna.ru/rules52534.html, 20040223.

${ }^{23}$ Пионтковский А., „Управляемая демократия стала ещё более управляемой“, Новая газета, 9 декабря 2003.

${ }^{24}$ „Борис Грызлов комментирует предварительные итоги выборов в Госдуму“, http://www.gryzlov.ru/ index.php?page =events\&id=326; Волков Ю., „Наша победа закономерна“, http://www.edinros.ru/ news.html?id=41486, 20040512. 
ti ,,administraciniai ištekliai“, kaip îvykusį faktą ir pabrèže jo panaudojimo visuotinumą. Kaip tik tai ir tapo galutinès išvados pagrindu - pažeistas vienas iš svarbiausių demokratinių rinkimų principų, reiškiančių, kad partijos ir kandidatai varžèsi nelygiavertemis konkurencijos sąlygomis ${ }^{25}$. Analogiška išvada, tik geriau argumentuota, po ménesio buvo pateikta galutinëje šios organizacijos ataskaitoje, kur administraciniai ištekliai susiję su vienos partijos iškèlimu per visuomenès informavimo priemo$n \mathrm{n}^{26}$. Taigi administracinius išteklius galima laikyti vienu iš pagrindinių veiksnių, turëjusiu įtakos rinkimų rezultatams - „valdžios partijos“ naudai, ką byloja nauja politinių jègų išsidèstymo tvarka. „Vieningoji Rusija“ labai sutvirtino savo pozicijas (1999 metu „,valdžios partijos“ laimèjimas - 81 mandatas) gavusi 306 (iš 450) deputatų mandatus. Komunistų partija gavo 54 mandatus ir išlaikè antrają poziciją, tačiau atitinkamai prarado 30 deputatų vietų, trečiojoje vietoje įsitvirtinusi rinkimų naujoké „Rodina“ gavo 38 mandatus. Ketvirtoje pozicijoje esantys liberalai demokratai pagerino savo rezultatus daugiau kaip dvigubai ir igijo teisę į 36 mandatus. Didžiausią nesėkmę patyrè dešiniosios partijos, nepatekusios į Dūmą ir praradusios net 52 mandatus ${ }^{27}$.

Taigi, remiantis ESBO stebėtojų komisijos atlikta analize, kurioje, beje, rasime ir nemažai teigiamų vertinimų (pavyzdžiui, pažymėta, kad išaugo Centrinės rinkimų komisijos profesionalumas), aiškiai konstatuojama, jog būta didelių konkurencingumo kriterijaus pažeidimų. Užfiksuotų pažeidimų skaičius ir jų dažnumas suteikia pagrindą kalbèti apie rusiškosios rinkimų demokratijos kontrolès elemento, atsiradusio dẻl nelegitiminių valdžios pastangų, egzistavimą ir apie vieno iš pagrindinio konkurenciją liudijančio elemento - lygių politinių varžybų sąlygų, t.y. laisvės ir sąžiningumo (angl. free and fair) reikalavimo, neatitikimą. Ir dar vienas pastebejjimas: akivaizdu, kad rinkimuose kovojo ne programos, bet biurokratija, kuri monopolizavo rinkejjus, tad rinkejjai balsavo ne pagal pateiktą programą, o tiesiog automatiškai arba vadovaudamiesi kitais motyvais atidave tiesę valdyti. Todèl galima drąsiai konstatuoti, kad nebuvo žengtas tolesnis pažangus žingsnis šia kryptimi, o rinkimu demokratiškumas visuomenės tebèra labai paviršutiniškai suvokiamas ir neturi nusistovejjusios tradicijos, taigi lengvai gali būti pažeidžiamas.

Nors demokratinio rinkimų proceso normų integralumas vykdomosios valdžios akivaizdžiai buvo pažeistas, prezidentas Putinas savo vertinimuose konstatuodamas ịvykusių rinkimų pozityvumą - Rusijos piliečiai turejjo eilinę galimybę išrinkti Dūmą, o „valstybė garantavo laisvą ir sąžiningą demokratinị pasirinkimą“, rinkimai „atspindèjo gyventojų realias simpatijas“ - pateikè pagrindinę išvadą, kad „tai dar vienas žingsnis stiprinant demokratiją “28. Turint omenyje ką tik kompetentingu organizacijų pateiktas nuostatas bei pridèjus tai, kad naujoje Dūmoje nebeliko parti-

\footnotetext{
${ }^{25}$ „OSCE: Vote Fundamentally Distorted“, http://www.themoscowtimes.com/stories/2003/12/09/ 001.html, 200402 01; “Выборы в Госдуму: предварительный доклад ОБСЕ”, 08 декабря 2003; http:/ www.urna.ru/rules/53557.html, 20040416.

${ }^{26}$ Russian Federation Elections to the state Duma 7 december 2003. OSCE/ODIHR Election Observation Mission Report, Warsaw, 2004, p. 12.

${ }^{27}$ Smith M., The Putin Presidency: Establishig Superpresidentalism, Conflict Studies Research Centre, Russian Series, February 2002, p. 2-3.

28 „Вступительное слово на совещании с членами Правительства, 8 декабря 2003 г. http://www.kremlin.ru/appears/2003/12/08/1931_type63378_56843.shtml, 20041009.
} 
jų, besitapatinančiu su demokratinèmis vertybèmis, išliko, tiesa, gerokai susilpnëjusi, kairiosios pakraipos opozicija. Tokios išvados motyvai yra išties sunkiai paaiškinami, tačiau suprantami prezidento vykdomos pragmatinès politikos kontekste. Putino požiūrị, ko gero, derètų interpretuoti taip: šiandieninejje valstybès ir visuomenès raidos stadijoje susiklosčiusios „,demokratiškų“ rinkimų realijos vertintinos vienareikšmiškai - kaip nemažas laimèjimas šalies modernizavimo srityje. Kita vertus, toks Putino politinis veiksmas aiškiai iškelia ị viešumą Vakarų valstybių ir Rusijos vertybinį skirtumą.

\section{Politinio ciklo tarp rinkimų naujienos}

Tolesnëje Rusijos vidaus politikos dienotvarkëje, susijusioje su rinkimų laikotarpiu, figūravo prezidento rinkimai, todèl savaime suprantama, kad sprendimus, priimtus šiuo metu, reikia vertinti atsižvelgiant ir ị šią aplinkybę. Tačiau netikètas ir paslaptingas Putino sprendimas atstatydinti vyriausybę pasinaudojant Konstitucijos 117 straipsnio 2 skirsniu, likus trims savaitems iki rinkimų dienos, tapo pagrindiniu prieš rinkimus vykusių viešų diskusijų, politikų ir politologų komentarų objektu.

Šis politinis manevras, pelnęs nemažai prieštaringų vertinimų tiek Rusijoje, tiek už jos ribų, telpantis ị Putino politikos strategijos ir taktikos rèmus, galima sakyti, yra logiškas jo politikos tęsinys. Nauja čia yra tiktai sprendimo netikètumas, beje, nebūdingas prezidento valdymo stiliui ir, kaip tiksliai pažymèjo kai kurie Rusijos dienraščiai („,Komsomolskaja pravda“, „Nezavisimaja gazeta“, „Moskovskij komsomolec"), atitiko Jelcino vyriausybių netikètų „rokiruočių“ tradicijas. Pasinaudodamas konstitucine teise atstatydinti vyriausybę savo nuožiūra, šiuo atveju likus dviem savaitems iki rinkimų dienos, prezidentas pademonstravo savo politines galias ir tai išreiške trumpa fraze: „Aš galiu, vadinasi, manau“. Be abejonès, priešingas veiksmas, kai vyriausybė atsistatydina taip pat pagal Konstituciją, bet iškart po prezidento rinkimų, būtų liudijęs Kremliaus politikos pastovumą ir demokratinị pobūdị.

Savo ruožtu vyriausybès atstatydinimas sudare palankią progą igyvendinti praktiškai jau anksčiau skelbtą „Vieningosios Rusijos“ rinkimų programos teiginị apie vykdomosios valdžios formavimą atsižvelgiant ị Valstybès Dūmos rinkimų rezultatus. Apie tokių politinių ketinimų rimtumą liudijo partijos vadovų, ypač tapusio Dūmos pirmininku B. Gryzlovo, patikinimas laikytis nuostatos, kad vyriausybės formavimas „turi remtis Dūmos dauguma“, bei ịsitikinimas, jog yra būtina, „,kad partijos kandidatai pretenduotų užimti ministrų vietas būsimoje vyriausybëje“"29 . Partija mažų mažiausiai tikejosi vadovauti atskiroms ministerijoms ir atrinko 5-6 galimus kandidatus iš deputatų korpuso ${ }^{30}$.

İtarimai, kad tai tiktai laiko klausimas, dar labiau sustiprèjo, kai prieš rinkimus Putinas pripažino, jog yra nusiteikęs svarstyti vyriausybès formavimo klausimą su parlamentine dauguma. Toks politinis sprendimas būtų palankiai ịvertintas Vaka-

\footnotetext{
${ }^{29}$ „Борис Грызлов за формирование правительства парламентского большенства“, http://www.edinros.ru/ news.html?rid=43\&id=50860, Борис Грызлов „Решение Президента - стратегическое“, http://www.edinros.ru/news.html? rid=43\&id=51380, 20040612

30 „Единороссы“ могут предложить несколько кандидатур“, http://www.edinros.ru/ news.html? rid=43\&id=52084, 20040604 .
} 
rų valstybių kaip konkretus, rimtas žingsnis, stiprinantis politinės institucinės sistemos demokratijos elementus, kas savaime būtų pasitarnavę išsklaidant stiprejjančias abejones dèl nukrypimo nuo demokratinès linijos. Tačiau partija pasieke tik minimalų rezultatą - ivvyko keli konsultaciniai susitikimai su prezidentu, dèl ko pavyko gauti pirmojo vicepremjero postą technineje vyriausybejje. Tai ir viskas, ką sau galëjo leisti šalies pirmasis politikas. Tokios prezidento konsultacijos labiau priminè formalią mandagumo procedūrą nei solidžias politikų konsultacijas. Beje, tai viename iš interviu atvirai pripažino ir partijos „Vieningoji Rusija“ sekretorius Valerijus Bogomolovas, kuris, tiesa, apsidraudè, sakydamas, kad reiškia asmeninę nuomonę ${ }^{31}$.

O vienintelį kadrini paskyrimą i vicepremjero pareigas galima vertinti kaip kompensaciją už patirtą moralinę nuoskaudą ir pernelyg didelius lūkesčius, patvirtintus viešais pareiškimais, užkertant kelią galimam spontaniškam nepasitenkinimui. Tačiau balsavimas už nepolitinio premjero Michailo Fradkovo kandidatūrą surinko Valstybès Dūmoje konstitucinès daugumos (352) balsus.

Vyriausybès atstatydinimo ir sprendimo prièmimo dèl naujos skyrimo būdas akivaizdžiai liudijo, kad prezidentas Putinas nenusiteikęs keisti ịprastinès politinės „,valdžios vertikalès" stiprinimo praktikos - pasidalyti, net ir minimaliai, kad ir su proprezidentine (kiekviename žingsnyje demonstruojančia ištikimybę) partija, politiniais ištekliais, isipareigojimais ir atsakomybe. Maskvos Karnegio tyrimo centro politologo Aleksandro Zudino vartojamą terminą „,vienodai nutolęs“ nuo (rus. ,pавноудаляемось“), tiksliai nusakantį prezidento santykius su kitais politinio režimo žaidejjais: oligarchais, kariniu ir politiniu elitu, dera patikslinti priskiriant proprezidentinę partiją „Vieningoji Rusija“, kuri (bent tuo momentu) buvo arčiausiai prezidento ${ }^{32}$.

Tačiau svarbiausia yra tai, kad toks Kremliaus principinis sprendimas suteikè rimtą pagrindą manyti, jog tolesnis politinès sistemos struktūrų, visų pirma politinès valdžios institucijų, liberalizavimas nelaikomas ne tik prioritetiniu uždaviniu, bet ir rimtesne politine problema, kitaip sakant, pasitenkinama „rinkimų demokratijos“ lygmeniu pasiektais minimaliais rezultatais. Pasitenkinama daliniu jos optimizavi$\mathrm{mu}$ ir tobulinimu, pavadintu administracine reforma, kas naujai vyriausybei reišké ministerijų skaičiaus sumažinimą beveik per pusę $e^{33}$.

Kodèl pragmatiškasis prezidentas Putinas atsisakè radikalesnio politinio sprendimo, ypač turint omenyje egzistuojantị palankių aplinkybių kompleksą, išties gali būti aiškinama tik prezidento atsargumu, kai kalbama apie politinio stabilumo užtikrinimą, apie kurį užsimenama kiekvienoje jo svarbesneje oficialioje kalboje ${ }^{34}$. Tiesą pasakius, sudarytoji vyriausybė, $i$ ją skyrus ministrus, atstovaujančius parlamentinei daugumai, tuo labiau proprezidentinei pozicijai, išties neturètų net minimalios įtakos prezidento galioms. Ko gero, klausimas „kodèl“ patenka į neatsakytų sąrašą su rubrika „Kas yra ponas Putinas?". Taigi ir šiuo atveju buvo išsaugotas valdžios status quo (legitimizuojant rinkimų būdu tokị politinị kursą) ir netgi, galima sakyti, sustiprintos Putino galios ir autoritarinis valdymas, kas atitinka ilgaamžes rusiškosios valdžios tradicijas.

\footnotetext{
${ }^{31}$ Kalbėdamas apie konsultacijų peripetijas, pagarsėjęs kur kas atviresnèmis kalbomis negu kiti partijos vadovai, V. Bogomolovas pareiškė: „Visus sprendimus, daugiau ar mažiau kardinalius, prezidentas priima savarankiškai“. „Фрадков мне сказал: расскажи о ЕР...“, Независимая газета, 200403 05, arba http://vbogomolov.ru/index.php?smi=27.

32 Žr.: 4 išnašą; Hale Henry E., „Russia’s Single-member-district Elections and The New Duma“, The Moscow Times, 2003 m. gruodžio $9 \mathrm{~d}$.
} 


\section{Prezidento rinkimų maratonas}

Paskutiniu reikšmingiausiu rinkimų ciklo ịvykiu turejo tapti prezidento rinkimai, tačiau iš anksto buvo aišku, kad jie virs formalia politine procedūra, nes neatsirado alternatyvios politinès figūros, galinčios bent kiek rimčiau konkuruoti su Putinu. Prieš rinkimus vykusios sociologinės apklausos, liudijančios prezidento aukštus populiarumo reitingus (iki 80 proc.), nepaliko net teorinių galimybių kitiems dalyviams ir iš anksto nulèmė rinkimų baigtị. Ši stabili ir aiškiai kontroliuojama prieš rinkimus susiklosčiusi situacija priminė Valstybės Dūmos rinkimus, kadangi iš rinkimų agitacinès dalies buvo eliminuotas pagrindinis varomasis komponentas - konkurencija ir programų kova.

Kita vertus, išankstinio nugalètojo tolesni veiksmai rinkimų laikotarpiu diskreditavo net formalų demokratinių rinkimų turinị. Pirmiausia - visokeriopas naudojimasis netiesiogine agitacija - kelionès po šali, nušviečiant jas kaip prezidento darbo keliones, tuo pat metu atsisakymas dalyvauti rinkimams skirtuose debatuose - vienareikšmiškai vertintina kaip nesuderinama su demokratiniais standartais. Antra, praktiškai rinkejjui nebuvo pateiktas aiškus strateginis veiksmų planas kaip rinkimų programos dokumentas. Prezidento trumpus samprotavimus apie šalies vystymosi pagrindines kryptis eilinis rinkèjas galëjo sužinoti (valstybinio kanalo RTR dèka) žiūredamas reportažus iš susitikimų su vadinamaisiais igaliotaisiais asmenimis apibendrinant ketverių metų prezidentavimo rezultatus ${ }^{35}$. Atrodo, kad taikymas tokios nekonkrečios rinkimų strategijos, konsoliduojančios įvairioms visuomenès grupėms priklausančius šalininkus, visiškai pasiteisina, nes ir per pirmuosius rinkimus buvo naudojama analogiška taktika ${ }^{36}$.

Tačiau reikšmingos informacijos pateikimo būdas, žinant, kad ji rinkimų metu beveik nebuvo plačiau aptarta ir svarstyta, dar kartą patvirtina nuomonę, kad prezidentas yra visiškai savarankiškas priimdamas principinius sprendimus, o politinis elitas iš esmės neturi realios galimybės dalyvauti šiame procese. Kita vertus, prezidento aiškiau negu iki tol išdèstytas požiūris ir politinès nuostatos yra vertos išsamesnio ir platesnio aptarimo, nes padeda geriau suvokti pagrindinę politikos kryptị ir bent minimaliai atskleisti politinès dienotvarkès turini - kokie vidaus politikos klausimai laikomi prioritetiniais ir ar jie susiję su mums labiausiai rūpima problema demokratijos perspektyvomis, ir pagaliau - kokie siūlomi sprendimo būdai.

Išvardijęs reikšmingiausius pirmosios kadencijos laimëjimus (sustabdyta valstybės dezintegracija, sureguliuotas oligarchų politizavimosi procesas, stabilizuota ekonominè situacija), Putinas iš naujo iškèlè ir sutelkẻ dėmesị i prioritetinę problemą -,žmonių gyvenimo kokybės kèlimą، ir numatè pagrindinius ekonominius veikimo būdus šiam tikslui pasiekti. Pirmiausia - ekonomikos plètros spartinimas tęsiant pradètas ir

\footnotetext{
${ }^{33}$ Указ № 314 „О системе и структуре федеральных органов исполнительной власти“, http://www.government.gov.ru/data/news_text.html?he_id=158\&news_id=13732, 20041012.

34 „Послание Федеральному Собранию Российской Федерации, 26 мая 2004 года“, http://www.kremlin.ru/sdocs/appears.shtml?type=63372, 20041025.

35 „Главе государства не следует заниматься собственной рекламой...“, http://www.vip.lenta.ru/doc/2004/ 02/12/putin/, 20041012.

${ }^{36}$ Гельман В., „Второй электоральный цикл и трансформация политического режима в России“, http://www.eu.spb.ru/socio/files/cycle_2s.pdf, 20041112.
} 
inicijuojant naujas reformas gyventojų aprūpinimo gyvenamuoju plotu, energetikos, mokesčių, susisiekimo ir socialineje srityse, silpninant dẻl pernelyg didelio valstybès dalyvavimo ūkiniuose procesuose atsiradusius ,,kai kuriuos neigiamus veiksnius ${ }^{\text {“37. }}$.

Nesigilinant į ekonominès politikos niuansus dera pažymėti, kad modernizavimo priemonių arsenalas telkiamas tiktai nuosaikiais metodais, primenančiais bent iš pirmo žvilgsnio - geriausius perestroikos laikus, kai buvo siekiama dalinėmis priemonemis pagerinti pavienius režimo elementus, kas atsispindi žodžiuose „,skatinti“, „,iekti““, „stiprinti“, „racionalizuoti“. Akivaizdžiai trūksta konkretumo ir aiškesnio požiūrio į egzistuojančias problemas ir būdus joms spręsti.

Antroji prioritetinè veikimo kryptis, kurios aprašymas, beje, užima tik vieną puslapi, užkoduota frazejje: „Tik laisvas žmogus gali garantuoti valstybės suklestejjimą“. Garantuodamas tolesnių politinių pertvarkymų demokratinį tęstinumą, Putinas konkretina, tai siedamas su savivaldos stiprinimu. Kalbama apie civilizuotos politinès konkurencijos, kuri galima tik egzistuojant įtakingoms ir stambioms politinems partijoms, būtinumą bei žadama baigti teisinès sistemos pertvarką. Svarbiausia prezidento proliberali pozicija atsispindi jo teiginiuose apie būtinumą formuoti ,visavertę, aktyvią pilietinę visuomenę šalyje“. Tiesa, kaip tai galima padaryti, pranešèjas nekonkretina, tik pamini vieną niuansą, kad ,ji negalima be laisvų ir atsakingų masinės informacijos priemonių. Tačiau tokia laisvè ir atsakomybẻ turi būti paremta teisine ir ekonomine baze, kurią sukurti-valstybès pareiga“"38. Kas turèta galvoje kalbant apie atsakomybę, belieka tik spèlioti, prisimenant geriausius „,kremlinologijos“** laikus, arba tiesiog palaukti, kol toks sumanymas bus pradètas igyvendinti praktiškai.

Putino siūlymus liberalizuoti politinị režimą derètų vertinti dvejopai. Pirma, ateities dienotvarkejje numatyti veiksmai yra ne tik netiksliai apibréžti turinio prasme, bet ir minimalūs. Juos reikia vertinti tiktai kaip nedidelius pakeitimus - patobulinimus, galinčius sudaryti sąlygas kardinaliems valstybiniams patobulinimams, pavyzdžiui, pilietinei visuomenei tolimoje ateityje sukurti. Galima sakyti, liberali prezidento pozicija netapo aiškesnè. Antra, abejonių nekelia ir tai, kad Putino credo negalima vertinti kaip galutinès ir ịteisintos programos, kurioje išdèstyti prioritetiniai veiksmai (tai, beje, galima taikyti ir siūlymams ekonomikos srityje) bus nuosekliai vykdomi. Kaip pažymi daugelis politologų, reformatoriškų veiksmų likimą lems konkreti politinè situacija ${ }^{39}$. Beje, netgi dauguma Rusijos ekspertų iš visų siūlymų skeptiškiausiai (dẻl jų igyvendinimo realumo) vertina būtent prezidento demokratinius ketinimus $^{40}$. Taigi galima drąsiai teigti, kad netgi tuo atveju, jei jie bus igyvendinti, tai neturès didesnès ịtakos politinio režimo demokratejimo procesui.

Kandidatų autsaiderių elgesys rinkimų metu buvo adekvatus susidariusioms aplinkybėms - pagrindinių partijų lyderiams atsisakius dalyvauti, jų vietą užèmé žmonès, kurie turèjo tiesiog mechaniškai užpildyti susidariusį vakuumą arba galëjo spręsti tik siauras partines ir savo asmenines problemas: komunistai iškẻlè Nikolajų Charitonovą, liberalų pozicijoms atstovaujanti Irina Chakamada tai panaudojo savo

${ }^{38}$ Žr.: 37 nuoroda.

${ }^{39}$ Rogoża J., „Wydźignęliśmy się z zapaści”: wystąpienie przedwyborcze Władimira Putina“, http:/ /www.osw.waw.pl/pub/koment/2004/02/030219.htm, 20041013.

${ }^{40}$, „редвыборная кампания глазами экспертов: В. Путин и другие“, http://bd.fom.ru/report/map/special/elecprez/d040938, 20041110. 
reklamai. Rimčiausiai mėgino pasipriešinti patriotiniu jẻgų idèjinis vadovas ir lyderis Sergejus Glazjevas, tačiau ir jo agitacinè mašina daugiau dirbo ateities politiniams dividendams užsitikrinti. Aukštesniųjų rūmų parlamento pirmininkas Sergejus Mironovas, beje, itin ištikimas prezidento šalininkas, iškèlè savo kandidatūrą, tarsi olimpiadoje, vien norėdamas tiesiog dalyvauti ir pailginti kandidatų suolelį. Ne ką mažesnị politinị spektaklị surengè ir iki tol nuolatinis prezidento rinkimų dalyvis liberaldemokratų lyderis ekscentriškasis Vladimiras Žirinovskis, suteikdamas galimybę juose dalyvauti savo asmeniniam sargybiniui Olegui Malyškinui.

Tiesa, kalbant apie rinkimus, verta pažymèti, kad ramiai ir nuobodžiai vykstant procesui iškilo viena mažyte problema. Remiantis sociologinèmis apklausomis (tik 48 proc. apklaustujų teigè tvirtai apsisprendę dalyvauti rinkimuose), Putinas galëjo nesurinkti daugiau kaip 50 proc. rinkèjų balsų, reikalingų, kad būtų išrinktas pirmajame rinkimų ture. Rinkejju aktyvumui padidinti buvo pasitelktas ịprastinis metodas - „administraciniai ištekliai“ bei paskelbtas agitacinis šūkis „Visi ị rinkimus!“. Čia vèl pasireiškè, kaip ir Valstybès Dūmos rinkimų metu, biurokratinio aparato uolumas ir iniciatyva, tačiau begalinis noras pasitarnauti iš anksto žinomam laimètojui pasiekẻ gerokai didesnị mastą, nors tai daryti nebuvo didesnès būtinybės.

ESBO atliktas valstybinių ir privačių televizijų tyrimas liudija, kad veikiančiam prezidentui buvo skirtas ypatingas dėmesys, o laiko požiūriu jis viršijo visų kandidatų eterio laiką kartu sudèjus, ypač tai atsispindejo regioninių, tiek valstybinių, tiek privačių (išskyrus kelias išimtis), televizijų programose ${ }^{41}$. Tokia išvada kaip neginčijamas demokratinių rinkimų standartų pažeidimas užfiksuota ir galutinëje šios organizacijos ataskaitoje, kurioje akcentuojami šie momentai: diskriminacinis visuomenès informavimo priemonių vaidmuo kandidatų atžvilgiu, dèl to tarp skirtingų politinių pozicijų sumažėjo konkurencija ir galimybès ịgyvendinti „turiningą pliuralizmąa“42 .

Prisiminus 2000 metų prezidento rinkimų ypatumus, kai tarp kandidatų vyko tam tikra laisva konkurencinè kova, o visuomenès informavimo priemonių ištekliai buvo daugmaž išlyginti, netgi pastabūs ir principingi tarptautiniai stebètojai pasitenkino nuosaikesniais vertinimais, todel pastarieji rinkimai vienareikšmiškai vertintini kaip konkretus žingsnis atgal ${ }^{43}$. Išties rinkimų rezultatai, kaip visi ir tikejosi, nepateikè staigmenu. Pasitelkus mobilizuojamuosius , administracinius išteklius“, dalyvavo 64,39 proc. rinkejjų (aktyvumas ankstesnių rinkimų metu $-68,7$ proc. ), o Putinas lengvai nugalejo, surinkęs 71,31 proc. balsų, t. y. 18,4 proc. daugiau, palyginti su ankstesniais rinkimais. Likusieji 5 pretendentai - autsaideriai tesurinko 22,60 proc. balsų, tarp jų daugiausia balsų gavo komunistų atstovas Charitonovas (13, 69 proc.), Glazjevas (4,10 proc.), demokratė Chakamada tenkinosi ketvirtaja vieta $(3,84 \text { proc. })^{44}$.

\footnotetext{
${ }^{41}$ Russian Federation: ODIHR Election Reports. 2004. Media Monitoring Results (Television) 12 February - 12 March, Media Monitoring Results (Regional State Television) (5 march 2004); Media Monitoring Results (Regional Private Television) (5 march 2004) http://www.osce.org/odihr/index.php?page =elections\&div= reports\&contry=ru, 20041012.

42 "Final Report on the Presidential Election in the Russian Federation", 14 Match 2004 (2 June 2004) http://www.osce.org/documents/odihr/2004/06/3033_en.pdf, 20041110.

43 Зудин А., „Кремль как субъект избирательной кампании“, Россия в избирательном цикле 1999-2000 годов, Москва: Гендальф, 2000, с. 107-108.

${ }^{44}$ Выборы Президента Российской Федерации 14 марта 2004 года, Протокол Центральной избирательной комиссии Российской Федерации о результатах выборов Президента Российской Федерации, http:// www.pr2004.cikrf.ru, 20041012.
} 
Rinkejjų pasitikejjimas Putinu neabejotinai ịspūdingas - gauta ne mažiau kaip 50 proc. balsų visuose be išimties regionuose: mažiausiai - Belgorodo srityje $-54,8$ proc., daugiausia - Ingušetijos Respublikoje - 99 proc. Už Putiną balsavo daugiau kaip 90 proc. Mordovijos, Dagestano, Baškirijos, Kabardos-Balkarijos regionų rinkejjų ${ }^{45}$. Atsakymas ị klausimą, kas lèmè tokius rodiklius, pakartojančius tarybiniu laikų rinkimų rezultatus ir dvasią, sunkiai paaiškinamas, matuojant demokratinių rinkimų masteliu. Tokị politinị dalyvavimą, kai balsuojama beveik be pasirinkimo (skirtumas tarp atejjusiųjų balsuoti ir balsavusių už Putiną tebuvo vos 1-3 proc.), galima pavadinti konjunktūriniu. Galima konstatuoti pažeidimus, tačiau priežasčiu pirmiausia derètų ieškoti tų visuomenès grupių socialinėse ir kultūrinėse tradicijose.

Tokį didelį Rusijos piliečiu pareikštą pasitikẻjimą, paramą Putino centristinei politinei pozicijai galima būtų aiškinti ịvairiomis priežastimis: asmenine politiko charizma, valdžios partijos parama, teigiama konjunktūra šalyje (politinès ir ekonominės situacijos dalinè stabilizacija, gyventojų pajamų augimas ir t.t.), administracinių išteklių naudojimu, kova su oligarchais. Tačiau itin svarbi yra ideologinè elektorato nuostata, grindžiama valstybès, kaip pagrindinès visuomenę organizuojančios ir jai vadovaujančios jẻgos, samprata. Stiprios valstybės, užtikrinančios piliečių saugumą, gerovę ir deramą tarptautinị statusą, - tokių bendrujų valstybės tikslų propagavimą Putinas inicijavo jau pirmoje rinkimų kampanijoje ir per visą kadenciją kiekviena pasitaikiusia proga juos tautai primindavo. Kova su oligarchais taip pat buvo afišuojama. Oligarchai vertinami kaip didžiausias blogis ir milžiniška kliūtis valstybės stiprinimo procese, kadangi jie atstovauja tik savo siauriems grupiniams interesams $^{46}$. Toks yra šiandieninès Rusijos politinių ir visuomeninių realijų kontekstas.

\section{Baigiamosios pastabos}

Pasibaigęs valdžios kaitos, t.y. rinkimų, ciklas galutinai apibrèžè valdžios statusą bent jau artimiausioje ateityje, orezultatas labiau nei akivaizdus-,„valdžios vertikalès“ jëgu tolesnè konsolidacija, itraukiant i ją̧ ir parlamento žemesniuosius rūmus, susiaurinant jų politinès autonomijos statusą. Prezidentinės partijos „Vieningoji Rusija“ demokratinès politinès iniciatyvos bent minimaliai išplèsti Valstybès Dūmos ir vyriausybès politinės veiklos lauką patyre akivaizdžią nesẻkmę dominuojančio politinio žaidëjo sprendimu. Tai liudija, kad vis labiau prarandama valstybės valdžių pusiausvyra, o politinė galia sutelkiama išimtinai prezidento ir jo administracijos rankose. Tiesą pasakius, išryškẻję ,,valdžios vertikalès" kontūrai nepasiekè tokio lygmens, ši sistema neįsišaknijo taip plačiai ir giliai kaip autoritarinëje Baltarusijoje, tačiau Putinas iš esmės disponuoja absoliučia asmenine niekieno nekontroliuojama valdžia, todèl galima sutikti su Kirilo Privalovo nuomone, kad nuo Stalino laikų dar niekas Rusijoje neturëjo tokios totalinės valdžios svertų ${ }^{47}$.

45 „Rinkèjų aktyvumas mainais ị pinigus“, Atgimimas, Nr. 11, 2004 m. kovo 19-25 d.

${ }^{46}$ Remiantis apklausų duomenimis, visų partijų, išskyrus Komunistų, elektoratas pirmenybę teikè ne partijos lyderiams, bet Putinui, pavyzdžiui, „Dešiniųu jęgų sajungos“ šalininkai 47 proc. atidavė prezidentui ir 11 proc. I. Hakamadai. Седов Л. А., „О чём вещают голоса избирателей?“, Общественные науки и современность, 2004, №. 5, с. 70-72.

${ }^{47}$ Idomus pastebejjimas, kad rinkimų ciklas užbaige šiuolaikinès Rusijos istorijos etapą, prasidèjusi 1985 m. Michailo Gorbačiovo pradèta „perestroika“. Privalov K., „La recette russe: la démocratie autoritaire“, Le débat, Paris, mai-aoūt 2004, numéro 130, p. 45, 62. 
Vieno asmens atstovaujama demokratija remiasi nuostata, kad pergalė prezidento rinkimuose suteikia teisę nugalètojui valdyti šalį tiktai savo nuožiūra, kuri formaliai reguliuojama (ką, beje, mègsta akcentuoti Putinas) Konstitucijos nustatytais laiko ir funkcijų rèmais. Tuo pat metu Valstybès Dūma ir valstybinè spauda turi tam tikrų galimybių, žinoma, paisydamos nustatytų ribų, daugiau ar mažiau kritikuoti prezidento politinius sprendimus. Po rinkimų prognozuojamas Rusijos politinès sistemos raidos kryptis - valdžios monocentristinès galios stiprinimas. Kliūtimis gali tapti tokie veiksniai kaip Rusijos dydis, atskirų regionų gerokai padidejęs savarankiškumas, ypač kai kurių regionų vadovų ambicijos, pagaliau sunkiai suvaldoma gausios biurokratijos savivalè.

Tai suvokdamas Putinas ieško ir suranda būdų, kaip pratęsti galių koncentravimo procesą. Tai liudija ir ryškiausias pavyzdys, naujas siūlymas - anuliuoti piliečiu teisę rinkti regionų vadovus tiesioginiuose rinkimuose, o šią procedūrą pavesti atlikti pačiam prezidentui, tiksliau sakant, pirmojo politiko pasiūlytus kandidatus tvirtinti regionams atstovaujančioms institucijoms. Tradiciškai monocentrizmo stiprinimas oficialiai motyvuojant pristatomas kaip kone vienintelis efektyvus būdas, padedantis Rusijos sąlygomis (nèra pilietinès visuomenès ir realiai veikiančios partinès sistemos) spręsti susikaupusias valdžios efektyvumo, kartu ir valstybės tolesnio modernizavimo problemas.

Sie žingsniai rodo, kad Putinas (itin iškalbinga jo frazė: „Politikos meną sudaro gebëjimas rasti aukso vidurị tarp būtino ir galimo“, padedanti suprasti ir minimaliai prognozuoti politiko veiksmus) nuosekliai ir metodiškai siekia sukurti griežtai centralizuotos valstybès modeli, pagal kuri prezidentas ir biurokratija visuomenejje atlieka vadovaujamą vaidmenį, kitaip sakant, visiškai savarankiškai traktuoja tautos interesus, nepaisydami jos pačios valios. Ši valdžia tokiu būdu apriboja ir susiaurina prisiimtą politinès socializacijos misiją, palikdama visuomenei menkas galimybes savarankiškai ugdyti pilietiškumą, kas, žinant eilinių piliečiu politinès kultūros lygị, yra itin svarbu.

Būtina pripažinti, kad bet kokiu atveju, net palankiausiomis aplinkybėmis, demokratinio proceso Rusijoje pažanga bus lèta ir veikiausiai tiktai dalinè, besiplètojanti pavienemis kryptimis. Pozityvesnès tendencijos greičiausiai gali formuotis tik iš viršaus, t. y. kontroliuojant valstybei, palaipsniui persitvarkant, sprendžiant ịsisenèjusias visuomenès vidaus problemas, tačiau tai pareikalaus nemažai laiko ir gebėjimų, o daugiausia - politinès valios. 